\title{
Development of Solar Energy in Chile and the World
}

\author{
Marco Rivera ${ }^{1}$, Diego Rojas ${ }^{1}$, Roberto Fuentes ${ }^{1}$ and Patrick Wheeler ${ }^{2}$ \\ ${ }^{1}$ Universidad de Talca, Curicó, Maule Region, 3341717, Chile. \\ ${ }^{2}$ The University of Nottingham, Nottingham, NG7 2RD, UK.
}

\begin{abstract}
Chile is a country with a huge potential for solar energy. This paper presents an analyses of the global situation of solar energy, identifying the geographical regions with the maximum potential source of solar energy. These areas tend to be in desert locations, since this is where the greatest irradiance is concentrated. A prediction of the potential situation in $\mathbf{2 0 3 0}$ is considered. The Chilean desert is considered, identifying the photovoltaic electricity potential and mentioning the current and future projects that will significantly increase the photovoltaic generation of the country.
\end{abstract}

Index Terms-Concentrated solar power, irradiation, nonconventional renewable energy, photovoltaic, solar energy, world perspective

\section{INTRODUCTION}

$\mathbf{S}$ SOLAR energy is a seemingly unlimited flow of energy from the sun. The energy is transmitted through sunlight, which is one of the clear examples of direct solar energy delivered to the Earth. Solar energy has been used since ancient times as a source of light and heat, such for example to light the Olympic torch using the sun's rays concentrated on a mirror [1]. However, the principle of the photoelectric effect and solar collectors were discovered in the 20th century [1]. Solar energy is characterized by being renewable, clean and inexhaustible [2]. This is why the use of this energy has attracted a lot of interest as a sustainable solution to meet energy demand and climate change, as presented in the Paris agreement [3]. Most countries in the world are developing energy policies for the inclusion of Non-Conventional Renewable Energies (NCRE) and in order to reduce the use of fossil fuels to reduce carbon dioxide emissions [4] generated by existing power plants that use fuels such as oil and coal. With the advancement of technology, photovoltaic solar energy is the most attractive solution in many countries, since it reduces energy dependence, increases energy security and allows sustainable development [5]. However, at the time of implementation it is necessary to know the geographical characteristics and the solar resource that each country has, therefore some countries have greater opportunities to incorporate solar technology due to their environmental conditions compared to other countries.

Solar energy is used mainly for the generation of electricity through photovoltaic panels and to heat water through solar thermal collectors [6]. With these two ways of converting solar

FONDECYT Regular Research Project 1191028 and FONDAP SERC Chile 15110019 . energy into usable energy, there are a wide variety of applications, such as solar lighting, heating, solar chargers, electricity generation, solar satellite and solar-powered transportation [5].

In Section II this paper presents a world view of solar energy, focusing mainly on the geography necessary for solar energy capture, world irradiance indices and solar energy projections. Section III presents an overview of solar energy in Chile, presenting important data on electricity generation, the photovoltaic electricity potential, in operation and future projects.

\section{SOLAR ENERGY: WORLD SCENERY}

The global outlook has been unfavourable for the market in the generation of electricity by solar energy since the pandemic event overlapped with the shortage of photovoltaic glass that had been afflicting the industry since 2018 [7] but which ended in the last quarter of 2020. After changes in Chinese policy [8], glass production returned strongly and demand for photovoltaic modules is expected to grow by $10 \%$ compared to 2020, reaching 153.8 [GW], as shown in Fig. 1 [9]. According to SGKPlanet, by 2021 the five main world producers of solar energy will be China, USA, Japan, India and Germany, where the sum of these countries will reach a total of 358.1 [GW] of power [10]. Although these figures are difficult to validate given that today it is complex to know the number of people who have installed their own solar panel systems and how much energy they collect to inject into the grid. However the data looks similar to the studies carried out by Enerdata [11].

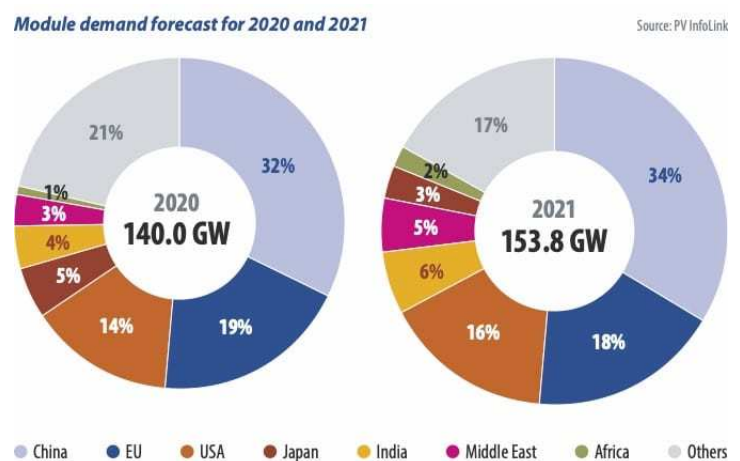

Fig. 1. Comparison of demand for solar modules between 2020 and 2021. Obtained from [9]. 


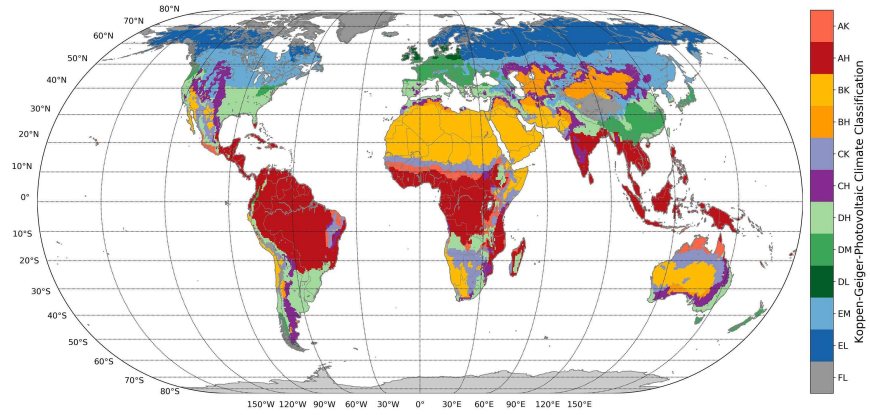

Fig. 2. Climate classification map. Obtained in [14].

\section{A. Geography in the development of solar energy}

Almost all of the energy available in the Earth's atmosphere, except geothermal energy, comes from the sun in the form of heat or in the form of radiation. The amount of energy the earth receives from the sun is approximately $1.37 \mathrm{~kW}$ per $\mathrm{m}^{2}$ [12]. Although this is the average energy density that the Earth's surface receives, clearly not all the surface receives the same amount of energy. The irradiance (unit of measurement of the solar radiation that reaches the Earth) depends on certain factors, mainly geographical, that is why the implementation of the generation of electricity through a solar source is more effective in certain places over others. Deserts are places with a large amount of irradiance given the absence of clouds and extensive arid territories. In 2019, the largest solar energy park in the United Arab Emirates was inaugurated [13], making good use of the properties of its geography.

\section{B. Deserts and irradiance indices}

Irradiance is the unit that measures the density of radiation from the sun that reaches the earth's surface and is measured in $W / m^{2}$. Based on the above, Ascencio-Vásquez [14] using the Köppen-Geiger-Photovoltaic (KGPV) method, designed a world climate classification where he contemplated irradiance in different climates to generate a color map with 24 are identified categories (see Fig. 2). In Fig. 2 the scale on the right consists of two letters, the first indicates the climatic zone (A-Tropical, B-Desert, C-Savanna, D-Temperate, E-Ice and FPolar) and the second letter corresponds to the irradiance level (L-Low, M-Medium, H-High and K-Very high).

Then, Ascencio-Vásquez generates Table I which indicates the percentage of presence of an irradiance category by climatic zone. From this it is clear that desert areas have greater irradiance compared to other areas. By having a higher concentration of radiation, deserts are potential sources of solar energy. Data from 2009 shows that 6 deserts as the places with the greatest irradiance that could be used for solar energy.

Table II summarizes these conditions [15]. The amount of energy that deserts receive in less than 10 hours is capable of supplying all the energy consumption of humanity for a year, in a utopian scenario. For a case closer to the current technological scope, consider an efficiency ratio of $8 \%$ in energy conversion, with covering an area of $1,100 \mathrm{~km}^{2}$ to
TABLE I

Percentage OF IRRAdiance By CLIMATIC ZONE ACCORDING TO KGVP

\begin{tabular}{lcccc} 
Zone & $\mathrm{L}$ & $\mathrm{M}$ & $\mathrm{H}$ & $\mathrm{K}$ \\
\hline Tropical & $0.04 \%$ & $2.80 \%$ & $11.11 \%$ & $1.77 \%$ \\
Desert & $0.00 \%$ & $0.17 \%$ & $3.36 \%$ & $12.05 \%$ \\
Savanna & $0.01 \%$ & $1.20 \%$ & $5.25 \%$ & $4.44 \%$ \\
Temperate & $0.76 \%$ & $4.45 \%$ & $7.58 \%$ & $0.84 \%$ \\
Ice & $20.24 \%$ & $10.12 \%$ & $2.10 \%$ & $0.10 \%$ \\
Polar & $8.95 \%$ & $1.17 \%$ & $0.61 \%$ & $0.80 \%$ \\
\hline
\end{tabular}

TABLE II

DESERTS WITH GREATER IRRADIANCE

\begin{tabular}{llll} 
Desert & Location & Area & Irradiance \\
\hline Atacama & South America & $139.869 \mathrm{~km}^{2}$ & $275 \mathrm{~W} / \mathrm{m}^{2}$ \\
Arabia & Western Asia & $2.589 .910 \mathrm{Km}^{2}$ & $270 \mathrm{~W} / \mathrm{m}^{2}$ \\
Sáhara & Africa & $9.064 .960 \mathrm{Km}^{2}$ & $260 \mathrm{~W} / \mathrm{m}^{2}$ \\
Great Basin & North America & $492.100 \mathrm{Km}^{2}$ & $220 \mathrm{~W} / \mathrm{m}^{2}$ \\
Greaty Sandy & Australia & $388.500 \mathrm{Km}^{2}$ & $210 \mathrm{~W} / \mathrm{m}^{2}$ \\
Takla Makan & Central Asia & $271.950 \mathrm{Km}^{2}$ & $210 \mathrm{~W} / \mathrm{m}^{2}$ \\
\hline
\end{tabular}

be distributed in one of the aforementioned deserts, it would be enough to supply about 20 [TW] of average power [16].

\section{Projections on solar energy}

Currently, almost all major environmental policies are promoted by the so-called 2015 Paris agreement, held at the COP21 [17] summit, where the agreement seeks to keep the global temperature rise below $1,5^{\circ} \mathrm{C}$.

That is why the different countries participating in the agreement strive to carry out efforts promoting non-polluting energies, this is how world powers such as the US, Japan, Germany and China, seek to implement more solar installations to cover part of the energy generation and reduce the gap by 2025.

To take an example, the US will have to quadruple the number of photovoltaic installations to reach the nearly 800 [GW] of power required to meet the proposed [18]. In a more general view, the cost of the solar installation is expected to decrease to $340-834$ [USD/kW] by 2030 , that is, a decrease of between $31 \%$ and $78 \%$ in the best case [19]. By 2030 it is expected that half of the world's energy supply will come from sustainable sources, and that in total $35 \%$ will be solar energy [20].

\section{SOLAR ENERGY IN CHILE}

Chile is a country located on the South American continent that borders Bolivia, Peru and Argentina. It consists of 16 regions, 56 provinces and 346 communes with a total population of about 18 million [21].

Due to its geographical location, the north of Chile is positioned as one of the areas with the highest concentration of average daily solar radiation in the world. It is possible to satisfy the energy demand of the entire country with the installation of photovoltaic solar panels in an area of $20 \mathrm{~km}^{2}$ [22].

For this reason, many international and national investors have invested capital in the installation of photovoltaic solar plants and are now concentrating on solar power plants. 
TABLE III

STATUS OF ERNC PROJECTS. DATA OBTAINED IN [27].

\begin{tabular}{lllll}
\hline Technology & Operation [MW] & Under Test [MW] & Building [MW] & EQR Approved \\
\hline Biomass & 466 & 6 & 166 & 0 \\
Wind & 2356 & 327 & 1958 & 103939 \\
Geothermal & 40 & 0 & 33 & 155 \\
Mini Hidro & 596 & 1 & 66 & 750 \\
Solar - PV & 3360 & 375 & 3116 & 23641 \\
Solar - CSP & 0 & 0 & 0 & 2032 \\
Total & 6818 & 709 & 5339 & 37517 \\
\hline
\end{tabular}

TABLE IV

SOLAR ENERGY PROJECTS IN OPERATION IN CHILE.

\begin{tabular}{lllll}
\hline Project & Technology & Region or city & Installed capacity [MW] & Operation date \\
\hline San Andrés & Solar photovoltaic & Atacama & 50.60 & 2014 \\
Diego de Almagro & Solar photovoltaic & Atacama & 28.05 & 2014 \\
Pozo Almonte Solar 3 & Solar photovoltaic & Tarapacá & 16.04 & 2014 \\
Llanos de Llampos & Solar photovoltaic & Atacama & 101.02 & 2014 \\
Solar Jama & Solar photovoltaic & Antofagasta & 52.65 & 2015 \\
Javiera & Solar photovoltaic & Atacama & 69.02 & 2015 \\
Salvador & Solar photovoltaic & Atacama & 68 & 2015 \\
María Elena & Solar photovoltaic & Antofagasta & 68 & 2015 \\
Luz del Norte & Solar photovoltaic & Atacama & 141 & 2016 \\
Conejo Solar & Solar photovoltaic & Antofagasta & 104 & 2016 \\
Pampa Solar Norte & Solar photovoltaic & Antofagasta & 69.39 & 2016 \\
Carrera Pinto & Solar photovoltaic & Atacama & 93 & 2016 \\
Quilapilún & Solar photovoltaic & Santiago & 103.02 & 2017 \\
Parque El Romero & Solar photovoltaic & Atacama & 196 & 2017 \\
Parque Finis Terrae & Solar photovoltaic & Antofagasta & 138 & 2017 \\
Quilapilún & Solar photovoltaic & Santiago & 103.02 & 2017 \\
Uribe Solar & Solar photovoltaic & Antofagasta & 52.8 & 2017 \\
Doña Carmen Solar & Solar photovoltaic & Valparaíso & 34.06 & 2017 \\
El Bolero & Solar photovoltaic & Antofagasta & 135.7 & 2018 \\
El Pelícano & Solar photovoltaic & Coquimbo & 108.1 & 2018 \\
Santiago Solar & Solar photovoltaic & Santiago & 92.73 & 2018 \\
\hline
\end{tabular}

TABLE V

SOLAR ENERGY PROJECTS THAT CAME INTO OPERATION BETWEEN 2020 AND MARCH 2021.

\begin{tabular}{lllll}
\hline Project & Technology & Region or city & Net power [MW] & Operation date \\
\hline PV park San Pedro & Solar photovoltaic & Antofagasta & 106 & $18-02-2021$ \\
PMGD Berrueco & Solar photovoltaic & de Ñuble & 9 & $06-02-2021$ \\
Venturada & Solar photovoltaic & de Ñuble & 9 & $13-02-2021$ \\
PMGD Lumbreras & Solar photovoltaic & Metropolitana & 3 & Feb.-2021 \\
PMGD FV El Membrillo & Solar photovoltaic & O'Higgins & 2.5 & Feb.-2021 \\
Sonnedix Atacama Solar II & Solar photovoltaic & Atacama & 170 & Jan.-2021 \\
PMGD Ciprés & Solar photovoltaic & del Maule & 9 & $19-01-2021$ \\
PMGD Quinantu Solar & Solar photovoltaic & del Maule & 9 & $15-01-2021$ \\
PMGD PFV EL Romeral & Solar photovoltaic & O'Higgins & 8 & Jan.-2021 \\
PMGD PFV Los Perales I & Solar photovoltaic & Valparaiso & 3 & Jan.-2021 \\
PMGD PFV santa Carolina & Solar photovoltaic & O'Higgins & 3 & Jan-2021 \\
PMGD PFV Don Jorge & Solar photovoltaic & O'Higgins & 3 & Jan.-2021 \\
PMGD PFV Caimi & Solar photovoltaic & Valparaiso & 0.2 & Jan.-2021 \\
USYA & Solar photovoltaic & Antofagasta & 52.4 & $07-12-2020$ \\
Andes Solar IIA & Solar photovoltaic & Antofagasta & 69.4 & $13-08-2020$ \\
Pepa Solar & Solar photovoltaic & Metropolitana & 9 & $12-08-2020$ \\
Granja Solar & Solar photovoltaic & Tarapacá & 105 & $30-06-2020$ \\
Parque FV Victoria & Solar photovoltaic & Antofagasta & 9 & $11-06-2020$ \\
LLanos del Potroso & Solar photovoltaic & Coquimbo & 9 & $07-05-2020$ \\
Almeyda & Solar photovoltaic & Atacama & 52 & $05-05-2020$ \\
Solar park Villa Alegre & Solar photovoltaic & del Maule & 9 & $31-03-2021$ \\
\hline
\end{tabular}

Due to the Paris agreement in 2015, Chile is committing to combat climate change through environmental policies that allow a sustainable future with low carbon dioxide emissions. From the energy point of view, Chile's goal is that by 2050, 70 $\%$ of the energy consumed will come from non-conventional renewable energies [23]. Therefore Chile wants to become a world leader in clean energy. It also has the goal of decarbonization or carbon-neutrality for the year 2050 and to obtain an efficient, sustainable and safe energy matrix. Therefore the use of energy from clean sources plays an important role. 
TABLE VI

FUTURE SOLAR ENERGY PROJECTS UNDER EVALUATION AND UNDER CONSTRUCTION IN CHILE.

\begin{tabular}{|c|c|c|c|c|c|}
\hline Project & Technology & RegionCity & Power [MW] & Datea & Stage \\
\hline PV solar park Nuevo Quillagua & Solar photovoltaic & Antofagasta & 100 & Feb.-2021 & Under test \\
\hline Photovoltaic project Azabache & Solar photovoltaic & Antofagasta & 59 & Feb.-2021 & Under test \\
\hline PMGD PFV Rauquén & Solar photovoltaic & Maule & 9 & Feb.-2021 & Under test \\
\hline New solar PV plant Casabermeja & Solar photovoltaic & Metropolitana & 9 & Feb.-2021 & Under test \\
\hline PMGD PFV Paine & Solar fotovoltaica & Antofagasta & 9 & Feb.-2021 & Under test \\
\hline PMGD Chillán Solar & Solar photovoltaic & Ñuble & 9 & Feb.-2021 & Under test \\
\hline PV park Torcazas & Solar photovoltaic & $\mathrm{O}^{\prime}$ Higgins & 3 & Feb.-2021 & Under test \\
\hline Solar Malinke & Solar photovoltaic & Metropolitana & 3 & Feb.-2021 & Under test \\
\hline Solar Concentration Plant Cerro Dominador & CSP & Antofagasta & 110 & Mar.-2021 (Operation) & Under construction \\
\hline PV park la Huella & Solar photovoltaic & Coquimbo & 84 & Mar.-2021 (Operation) & Under construction \\
\hline Caracas plant & Solar photovoltaic & Coquimbo & 18 & May.-2021 (Operation) & Under construction \\
\hline Teno uno plant & Solar photovoltaic & Maule & 9 & May.-2021 (Operation) & Under construction \\
\hline Machicura park & Solar photovoltaic & Maule & 9 & May.-2021 (Operation) & Under construction \\
\hline Los Corrales del Verano park & Solar photovoltaic & Metropolitana & 9 & May.-2021 (Operation) & Under construction \\
\hline Sol de Lila park & Solar photovoltaic & Antofagasta & 163 & Jun.-2020 (Operation) & Under construction \\
\hline Sol del Desierto park - fases I y II & Solar fotovoltaica & Antofagasta & 230 & Jun.-2021 (Operation) & Under construction \\
\hline PMGD PV Los Molinos & Solar photovoltaic & Metropolitana & 9 & Jun.-2021 (Operation) & Under construction \\
\hline Domeyko 2 project & Solar photovoltaic & Antofagasta & 204 & Jul.-2021 (Operation) & Under construction \\
\hline Sol de los Andes & Solar photovoltaic & Atacama & 89.4 & Jul.-2021 (Operation) & Under construction \\
\hline Extension Finis Terrae stage 1 & Solar photovoltaic & Antofagasta & 126.2 & Aug.-2021 (Operation) & Under construction \\
\hline Valle del Sol project & Solar photovoltaic & Antofagasta & 163 & Aug.-2021 (Operation) & Under construction \\
\hline PMGD PV QUetena & Solar photovoltaic & Antofagasta & 9 & Sep.-2021 (Operation) & Under construction \\
\hline Diego de Almagro project 1 y 2 & Solar photovoltaic & Atacama & 104 & Sep.-2021 (Operation) & Under construction \\
\hline PV projectCoya & Solar photovoltaic & Antofagasta & 192 & Dec.-2021 (Operation) & Under construction \\
\hline Pampa Tigre park & Solar photovoltaic & Antofagasta & 100 & Dec.-2021 (Operation) & Under construction \\
\hline Solar project Valle Escondido & Solar photovoltaic & Atacama & 105 & Dec.-2021 (Operation) & Under construction \\
\hline Andes II B & Solar photovoltaic & Antofagasta & 180 & Feb.-2022 (Operation) & Under construction \\
\hline
\end{tabular}

The factors that has allowed Chile to position itself as an example of the use of energy from renewable sources is due to established environmental policies, established energy policies, regulatory framework [24] and favourable environmental conditions for the use of renewable energy. Among the main laws are Law 20,571 for distributed generation, Law 20,365 that establishes the tax exemption with respect to solar thermal systems and Law 20,698 of expansion of the energy matrix through non-conventional renewable sources (NCRE) [25].

The distribution of electricity generation by nonconventional renewable sources is presented in Table III. It can be seen that the installed capacity of ERNC is 6,818 MW until April 2021 and photovoltaic solar energy leads the way with $3,360 \mathrm{MW}$ of operation (equivalent to $12.88 \%$ of the country's total installed capacity in electricity generation sources [26]). However, the projects that have most approved the environmental rating (RCA) are related to photovoltaic solar energy. Also the solar power concentration (csp) has a relevant number of $2032 \mathrm{MW}$ in the environmental rating. The figures reveal that the use of solar energy in Chile is taking a lot of interest, due to the great potential of the solar resource that the country contains. In [28], the geographically distributed photovoltaic electric potential is presented, where in the north of Chile (Arica, Iquique and Antofagasta) they contemplate the highest annual photovoltaic electric potential between approximately 2118 and $2410 \mathrm{kWh} / \mathrm{kWp}$. On the other hand, further south, in the cities of Temuco and Valdivia they have a potential between 1241 and $1534 \mathrm{kWh} / \mathrm{kWp}$. As a result of this, most of the large photovoltaic solar generation projects are located in the north of Chile.
The photovoltaic electric potential is due to the amount of solar radiation that affects certain geographical places in Chile, being the north where there is greater normal direct irradiance of about $3652 \mathrm{kWhm}^{2}$ (in [28]). Further south in the cities of Valdivia and Temuco they have a normal direct irradiance of approximately between 1095 and $1241 \mathrm{kWhm}^{2}$. Therefore, Chile is one of the countries with the highest solar irradiance indices in the world, a product of which it is considered a country with high solar energy capacity. Due to the large solar potential that exists in Chile, there are a large number of projects associated with photovoltaic solar generation. In Table IV some projects already in operation in the generation of electricity in Chile are presented. Table V shows some projects that came into operation between 2020 and March 2021 installed in Chile. The acronym PMGD corresponds to Small Means of Distributed Generation, which are projects that in recent times have been incorporated for the generation of electricity. Additionally, in Table VI presents some comming project which are under different stages to be installed in Chile

\section{Conclusions}

Talking about environmental policies today is synonymous with talking about the 2015 Paris agreement, and this work is an example. The largest current projects in solar energy are driven by this agreement, both globally and locally. This is because, so far, the most promising way to deliver is to promote renewable energy facilities. This study shows that despite the pandemic situation, the solar energy market has not decreased in demand, even, against all expectations, it increased demand by $10 \%$ this year compared to the previous one. 
Relevant geographical factors in energy potential were also analysed, where it was observed that desert places have the most favourable conditions for electricity generation since they have the highest irradiance indices, followed by tropical areas. In global terms, everything indicates that in 2030 more than a third of the energy consumed will be produced by solar energy. As for Chile, it has the highest irradiance indices in the world, which makes it a country with the potential to be pioneers in the matter. This is why it set itself the goal of achieving energy production almost entirely from solar energy. In the last year, 21 projects came into operation, so in this time the total number of solar energy projects that have projects in the accounts doubled since 2014, which indicates a future for renewable energy in the country.

\section{ACKNOWLEDGMENT}

The authors are grateful for the financial support of the FONDECYT Regular Research Project 1191028, Universidad de Talca, The University of Nottingham and FONDAP SERC Chile 15110019.

\section{REFERENCES}

[1] P. Giese. [Online]. Available: https://www.ammonit.com/es/wind-solarwissen/solarenergie/470 historia de la energia

[2] I. F. Aldariz, "Energía solar: QuÉ es, tipos, usos, ventajas y desventajas," Jan 2021. [Online]. Available: https://www.greenteach.es/laenergiasolartodosobreella/

[3] Minrel, "A cinco años del acuerdo de parís, chile reafirma su compromiso en la lucha contra el cambio climático.” [Online]. Available: https://minrel.gob.clnoticias-anterioresacincoanosdelacuerdodeparischilereafirmasucompromisoenla

[4] "El aporte de las energías limpias a la reducción de emisiones." [Online]. Available: https://energia.gob.cl/noticias/nacional/el-aporte-delas-energias-limpias-la-reduccion-de-emisiones

[5] "Beneficios de la energía solar," Sep 2019. [Online]. Available: https://blog.celsia.com/new/beneficiosdelaenergiasolar/

[6] Swissolar, "Swissolar." [Online]. Available: https://www.swissolar.ch/en/about-solar/solar-construction/activeand-passive-use-of-solar-energy/

[7] "Escasez de vidrio para paneles enlentecería el impulso climático." [Online]. Available: https://www.infobae.com/america/agencias/2020/11/05/escasez-devidrio-para-paneles-enlenteceria-el-impulso-climatico/

[8] "China: fabricantes de módulos piden intervención del gobierno." [Online]. Available: https://www.review-energy.com/solar/china-fabricantesde-modulos-piden-intervencion-del-gobierno

[9] "Infolink consulting." [Online]. Available: https://www.infolinkgroup.com/en

[15] "Cómo los desiertos podrían proporcionar toda nuestra energía." [Online]. Available: https://faircompanies.com/articles/comolos-desiertos-podrian-proporcionar-toda-nuestra-energia/
[10] “¿cuáles son los principales países productores de energía solar?" [Online]. Available: https://sgkplanet.com/cuales-son-los-principalespaises-productores-de-energia-solar/

[11] "Anuario estadístico mundial de energía 2020." [Online]. Available: https://datos.enerdata.net

[12] P. Hersch and K. Zweibel, "Basic photovoltaic principles and methods," vol. 1, no. 2, 2 1982. [Online]. Available: https://www.osti.gov/biblio/5191389

[13] "Mohammed bin rashid al maktoum solar park - a leading project that promotes sustainability in the uae." [Online]. Available: https://www.dewa.gov.ae/en/about-us/media-publications/latestnews/2019/03/mohammed-bin-rashid-al-maktoum-solar-park

[14] J. Ascencio-Vásquez, K. Brecl, and M. Topič, "Methodology of köppen-geiger-photovoltaic climate classification and implications to worldwide mapping of pv system performance," Solar Energy, vol. 191, pp. 672-685, 2019. [Online]. Available: https://www.sciencedirect.com/science/article/pii/S0038092X19308527

[16] "Total primary energy supply — from sunlight." [Online]. Available: https:www.ez2c.demlsolar_land_area

[17] "Acuerdo de parís." [Online]. Available: https://unfccc.int/files/meetings/paris_nov_2015/app lication/pdf/paris_agreement_spanish_.pdf

[18] "Disminución de la brecha del cop21 mediante la energía solar." [Online]. Available: https://www.interempresas.net/Energia/Articulos/159621-Disminucionde-la-brecha-del-COP21-mediante-la-energia-solar.html

[19] "El futuro de la energÍa solar fotovoltaica." [Online]. Available: https://bit.ly/3sT8LgG

[20] B. Grassi, E. A. Piana, G. P. Beretta, and M. Pilotelli, "Dynamic approach to evaluate the effect of reducing district heating temperature on indoor thermal comfort," Energies, vol. 14, no. 1, 2021. [Online]. Available: https://www.mdpi.com/1996-1073/14/1/25

[21] "Chile," Apr 2021. [Online]. Available: https://es.wikipedia.org/wiki/Chile

[22] E. de energía INDAP, "Recurso solar y uso del explorador solar," Noviembre 2018. [Online]. Available: https://www.indap.gob.cl/docs/default-source/default-documentlibrary/ppt-3-recurso-solar.pdf?sfvrsn=0

[23] "Las ambiciosas metas de chile para liderar en energía limpias y renovables," Sep 2019. [Online]. Available: https://laboratorio.latercera.com/tiempo-de-actuar/noticia/metaschile-energia-limpias-renovables/821478/

[24] "Bloombergnef: Chile alcanza primer lugar en energías limpias dentro de países en desarrollo." [Online]. Available: https://www.revistaei.cl/2020/12/09/bloombergnefchilealcanzaprimerlugarenenergiaslimpiasdentrodepaisesendesarrollo/

[25] B. d. C. Nacional, "Biblioteca del congreso nacional: Ley chile." [Online]. Available: www.bcn.cl/leychile

[26] "Capacidad instalada - energía abierta: Comisión nacional de energía." [Online]. Available: http:energiaabierta.clvisualizacionescapacidadinstalada

[27] M. de Energía, "Reporte mensual ernc," Abril 2021. [Online]. Available: https://www.cne.clwpcontentuploads202103RMensual_ERNC_v202103.pdf

[28] "Solar resource maps of chile." [Online]. Available: https://solargis.commapsandgisdatadownloadchile 